\title{
Where we Come from and where to Go: Six Decades of Botanical Studies in the Mediterranean Wetlands, with Sardinia (Italy) as a Case Study
}

\author{
Alba Cuena-Lombraña ${ }^{1}$ (D) $\cdot$ Mauro Fois $^{1}$ (D) $\cdot$ Annalena Cogoni ${ }^{1}$ (D) $\cdot$ Gianluigi Bacchetta $^{1}$ (D)
}

Received: 21 January 2021 / Accepted: 24 May 2021 / Published online: 21 June 2021

(C) The Author(s) 2021

\begin{abstract}
Plants are key elements of wetlands due to their evolutionary strategies for coping with life in a water-saturated environment, providing the basis for supporting nearly all wetland biota and habitat structure for other taxonomic groups. Sardinia, the second largest island of the Mediterranean Basin, hosts a great variety of wetlands, of which 16 are included in eight Ramsar sites. The 119 hydro- and hygrophilous vascular plant taxa from Sardinia represent the $42.6 \%$ and $37.9 \%$ of the number estimated for Italy and Europe, respectively. Moreover, around 30\% of Sardinia's bryological flora, which is made up of 498 taxa, is present in temporary ponds. An overview at regional scale considering algae is not available, to our knowledge, even though several specific studies have contributed to their knowledge. In order to find the most investigated research themes and wetland types, identify knowledge gaps and suggest recommendations for further research, we present a first attempt to outline the work that has been hitherto done on plants in lentic habitats in Sardinia. Three plant groups (algae, bryophytes and vascular plants), and five research themes (conservation, ecology, inventory, palaeobotany and taxonomy) were considered. After a literature review, we retained 202 papers published from 1960 to 2019. We found that studies on vascular plants, as plant group, were disproportionately more numerous, and inventories and ecology were the most investigated research themes. Although efforts have recently been made to fill these long-lasting gaps, there is a need for updating the existing information through innovative methods and integrative approaches.
\end{abstract}

Keywords Freshwater ecosystems $\cdot$ Lentic water bodies $\cdot$ Literature review $\cdot$ Mediterranean islands $\cdot$ Trends in botany $\cdot$ Wetland conservation

\section{Introduction}

Plants are structural components of most aquatic and terrestrial ecosystems and are largely studied for their ecological and economic significance. Wetland plants are of interest due to of their particular evolutionary strategies for coping with life in water-saturated environments (Cronk and Fennessy 2016) and because they provide the basis for supporting all wetland biota and habitat structure for other taxonomic groups (Legrand et al. 2003). They strongly influence water chemistry, both

Mauro Fois

mfois@unica.it

1 Dipartimento di Scienze della Vita e dell'Ambiente, Università degli Studi di Cagliari, Viale S. Ignazio da Laconi, 13,

09123 Cagliari, Italy acting as nutrient sinks through absorption and moving compounds from the sediment to the water column (Webb et al. 2012), and have the ability to improve water quality by absorbing nutrients, metals, and other contaminants (Kao et al. 2003). Plants also influence hydrological and sediment processes, by regulating water flow, crest stability and soil formation (Saaltink et al. 2018).

Wetlands are crucial for plant diversity. Despite their general low endemicity rate (Santamaría 2002; Hobohm and Bruchmann 2011), plants living in wetlands, and in interconnected ecosystems such as coastal sand dunes, often exist in scattered and threatened populations (Deane et al. 2016; Cheng et al. 2020). With wetlands experiencing an estimated $50 \%$ loss over the last century (Davidson 2014), their conservation importance is particularly recognised in several multilateral environmental agreements, such as the Water Framework Directive (WFD 2000/60/EC) and the Ramsar Convention (Ramsar Convention Secretariat 2015). Wetland 
plants are endangered by the same forces that generally threaten these ecosystems, including human activities such as wetland draining or filling, hydrologic alterations, chronic degradation due to nonpoint source pollution, and invasion of exotic species (Cronk and Fennessy 2016; Bolpagni et al. 2018). There are increasing concerns regarding the effects of climate change, as sea-level rise, salinisation or desertification (EC 2017). To solve these problems, plants are also represent the tools used by wetland managers and researchers in the monitoring, conservation, and management of wetland areas (Cronk and Fennessy 2016). However, conservation and even basic knowledge gaps and debating issues often exist. Van Rees et al. (2020) suggest considering freshwater environments as a 'third realm' that cannot be lumped together with policies for terrestrial or marine habitats. It is even debated whether a plant is aquatic or should be considered for monitoring aquatic habitats (Deane et al. 2016), and the taxonomic delimitation among several plant groups is still unclear (Deil 2005). Also, the ecology, distribution patterns, and dispersion of most plants, especially algae and bryophytes, are often overlooked (Santamaría 2002; Dalla Vecchia et al. 2020).

In Sardinia, more than the global average reported above, around $90 \%$ of wetlands, especially along the coast, have been destroyed or heavily modified during the last 100 years to eliminate malaria and for agricultural, industrial, or military purposes (Massoli-Novelli and Mocci-Demartis 1989). More recently, tourism development has become another threatening factor, especially near coastal wetlands (Ferrarini et al. 2020). Furthermore, 134 alien vascular plant species, out of the 481 inventoried for the whole Sardinia, were recorded in wetlands (Mayoral et al. 2018). Several temporary wet habitats with populations of rare taxa are threatened by invasive plant species such as Cyperus eragrostis or Campylopus introflexus (Cogoni et al. 2009; Mayoral et al. 2018). Other coastal and inland wetland types are also severely altered and threatened by other invasive alien plant species such as Hydrocotyle ranunculoides, Cortaderia selloana, and Eichornia crassipes or by increasing blooming events of Chattonella subsalsa (Brundu et al. 2013; Satta et al. 2017; Mayoral et al. 2018). To date, there has not been any extensive overview of wetland plants in Sardinia. Considering the wide interest and application of plants studies in (palaeo)landscape, population ecology, management, and conservation, a data collection and a synthesis are overdue.

Here, we present a critical bibliographic research of the modern literature, from the 1960s onwards, comprising original botanical studies in Sardinian wetlands (including species of algae, bryophytes and vascular plants). This research was restricted to lentic wetlands (hereafter referred to as wetlands), that is, any wetland type defined by the Ramsar Convention Secretariat (2013) with the exclusion of streams, rivers, and other running water. Sardinia is a representative
Mediterranean study case of special biological interest due to of its central geographic position and the great variety and numbers of wetland types and species related to both the African and European continents that it hosts (Vogiatzakis et al. 2016; Murphy et al. 2019). This research provides a comprehensive starting point for the study of Sardinian wetlands, a discussion of the typology of researches carried out so far, and new perspectives to acquire effective knowledge (and implement conservation) from plants and wetlands. In particular, we aimed to (1) investigate the state-of-the-art studies on Sardinian wetland plants; (2) find the most investigated research themes and wetland types; and (3) identify knowledge gaps and provide recommendations on how such research might be improved and used in wetland management.

\section{Materials and Methods}

\section{Research Area and Plant Taxa}

Sardinia is the second-largest island in the Mediterranean Basin, with a surface of 24,090 $\mathrm{km}^{2}$. Recently, 2501 wetlands have been inventoried in Sardinia, covering a total surface area of $494.2 \mathrm{~km}^{2}$ (ca $2 \%$ of the Sardinian territory). The full dataset is available online, as part of the Mediterranean Island Wetlands project (https://italiaiswet.it). Among the various wetlands on the Sardinian territory, 16 (covering about ca. $92 \mathrm{~km}^{2}$, mainly concentrated along the coast of the provinces of Cagliari and Oristano) are within the eight designated Ramsar sites, and 116 are included in the Natura 2000 network. In terms of inland wetlands, at least $90 \%$ of drinking water is stored in more than 40 reservoirs (Sechi and Lugliè 1996). Very common are small and very small artificial ponds (approx. $<1 \mathrm{ha}$ ) in the agro-pastoral context, and only three are recognised as natural lakes: Lago di Baratz in the northern-western part of the island, and Piscina Morta (Arisci et al. 2003) and Stagnu 'e Forru in the southwest (Ginesu 2012). Last but not least, the numerous temporary small ponds were highlighted as the most interesting, though insufficiently investigated, inland wetland type (Bagella et al. 2009; Cogoni et al. 2016). Despite the efforts already made regarding wetland conservation in Sardinia, recent studies on wetland plants evidenced the need for an improvement of legal protection (EEA 2015; Becker 2019) - Bagella et al. (2013) and Fois et al. (2018) highlighted the necessity of protection measures as, for instance, several wetland plants are still not included in the Natura 2000 network.

The Sardinian vascular flora consists of 2782 taxa, 186 of which are exclusive endemics, representing ca $7 \%$ of the native flora (Fois et al. 2017; Bartolucci et al. 2018). On the other hand, about $28 \%$ of the 481 non-native vascular plants reported in Sardinia are living in wetlands (Mayoral et al. 2018). A recent inventory of strictly hydro- and hygrophilous vascular 
plants in Italy identified 119 species for Sardinia, representing $42.6 \%$ and $37.9 \%$ of the numbers estimated for Italy and Europe, respectively (Bolpagni et al. 2018).

Knowledge of bryophyte and algae species' diversity and distribution is still far lower than that of vascular plants, and the less common studies are mainly concentrated on small or specific areas. According to the checklists of Sardinian (Cogoni et al. 1999, 2016) and Italian bryophytes (Aleffi et al. 2020), Sardinia's bryological patrimony is made up of 498 taxa (399 Bryophyta, 94 Marchantiophyta, and four Anthocerotophyta), around $30 \%$ of which inhabit temporary ponds, where both terrestrial and aquatic habitats are present a transitional characteristic that explains their high biodiversity (Cogoni et al. 2016; Filippino 2018). Even less is known about the algae flora of Sardinian wetlands. To our knowledge, an overview at the regional scale is not yet available, even though specific studies have significantly contributed to the knowledge of, for instance, charophytes (Becker 2019) and freshwater microalgae (Malavasi 2012).

\section{Literature Search}

The term 'Wetland plants' includes: species of algae, as they are a component of wetland primary productivity and an important element of these habitats, and they obtain their primary chloroplasts directly by engulfing cyanobacteria (CavalierSmith 1998); and species of bryophytes and of vascular plants that grow (both obligatory and not-obligatory) in water or in saturated soils. All are hereafter denominated as 'plant groups'.

We conducted a literature review of papers investigating wetlands plants published from 1960 to December 2019, as due to related historical problems, for instance, the endemic presence of malaria, wetlands were underappreciated in biological sciences before that period. Another reason for our choice was avoiding inaccurate or unbiased data due to poor and scattered availability in digital archives. Similarly, all 'grey literature', such as books, technical reports, and academic theses, was not considered, despite its potentially rich information unreported elsewhere. A research of the peer-reviewed articles was carried out, both in Italian and English, in Google Scholar as well as in Web of Science and Scopus with the terms 'wetland*', 'marsh*', 'lagoon*', 'saline*', 'estuar*', 'delta*', 'pond*', 'pool*', 'lake*', 'freshwater*', 'dam', 'dams', 'swamp*', 'reservoir*' or 'barrag*' combined with 'Sardinia*' and 'plant*', 'phyto*', 'bryophyt*' 'diatom*' or 'alga*' as well the same terms in Italian.

After duplicate removal, title screening and abstract revision, 202 papers were fully reviewed and retained because they presented original studies about plants in the Sardinian wetlands (Fig. 1; see Supplementary Information 1 for further details). The wetland study sites of each paper were georeferenced in the Quantum Geographic Information

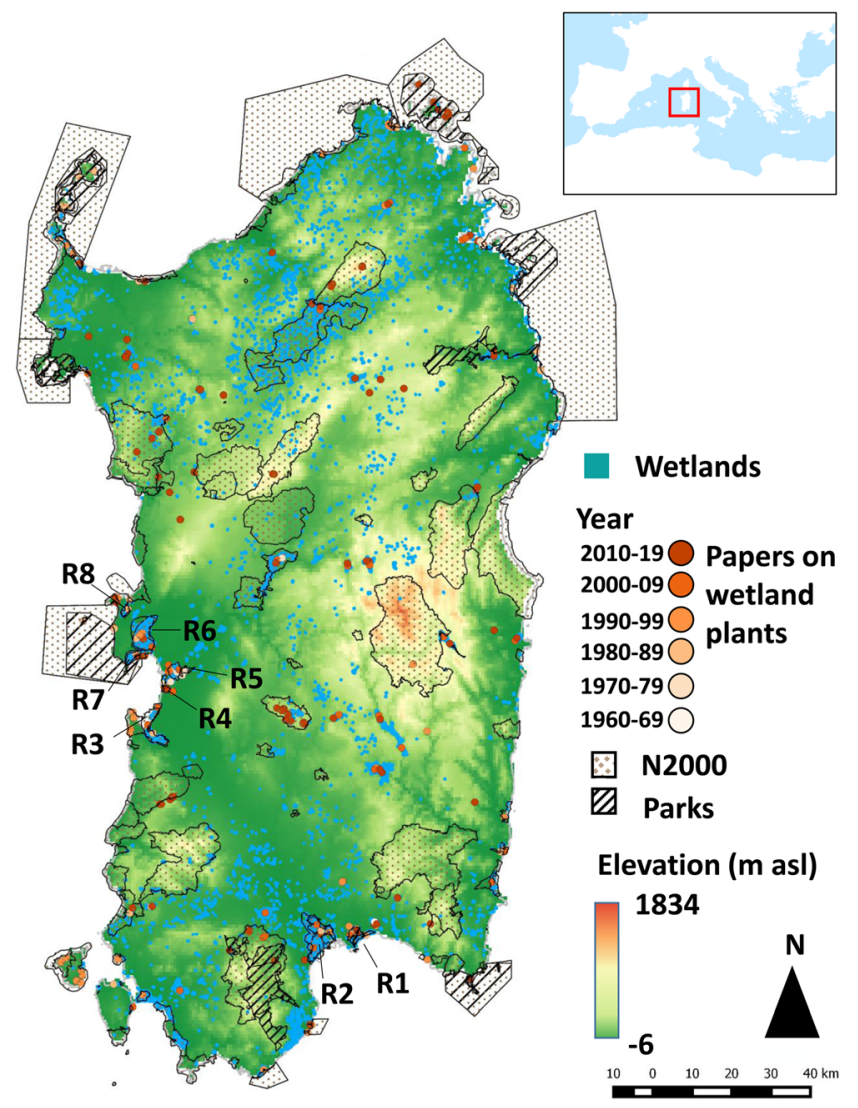

Fig. 1 Sardinia's position within the Mediterranean Basin and spatial distribution of papers on Sardinian wetland plants published from 1960 to December 2019. Wetlands are those included in the Italian Island Wetlands - ItIsWet database and available on-line at http://www. italiaiswet.it. Natura 2000 sites (N2000) and national and regional parks (Parks) were retrieved from the Sardinian geoportal at https://portal. sardegnasira.it. The eight Ramsar sites $(R)$ are also included

System (QGIS) and overlaid on the network of protected areas. Spatial datasets were downloaded from the regional geoportal (https://portal.sardegnasira.it) and included all Natura 2000 and Ramsar sites, and national and regional parks.

\section{Research Themes and Wetlands Types}

We classified all research papers according to the main argument considered, into five research themes: conservation, ecology, inventory, palaeobotany, and taxonomy (see details in Table 1).

Wetland types described in the analysed papers were identified according to the Ramsar classification (Ramsar Convention Secretariat 2010, 2013), which divides wetlands into three main categories: marine and coastal, inland, and human-made. For further detailed subdivisions of each main category, we followed guidelines for identifying specific wetland types (Ramsar Convention Secretariat 2010). 
Table 1 Details of research themes

\begin{tabular}{|c|c|c|}
\hline $\begin{array}{l}\text { Research } \\
\text { theme }\end{array}$ & Definition & Examples \\
\hline Conservation & $\begin{array}{l}\text { Broad group of studies aiming to improve the conservation status, } \\
\text { as well as the assessment or strategies to prevent plant } \\
\text { extinction. Recovery plans, restoration activities, and new } \\
\text { challenges are also included in this theme. }\end{array}$ & $\begin{array}{l}\text { Sensitivity of ephemeral wetland (Bagella et al. 2013), Red Lists } \\
\text { (Cuena et al. 2013), enhance local biodiversity (De Martis et al. } \\
\text { 2016). }\end{array}$ \\
\hline Ecology & $\begin{array}{l}\text { Papers analysing relationships between wetland plants and } \\
\text { physical environment, more specifically abiotic parameters and } \\
\text { their influence on abundance, distribution, etc. Abiotic factors } \\
\text { include temperature, quality water/habitat, } \mathrm{pH} \text {, salinity, } \\
\text { seasonality, etc. }\end{array}$ & $\begin{array}{l}\text { Temporal distribution and environmental variables (Lugliè et al. } \\
\text { 2001); ecology (Cogoni et al. 2006); dynamics in relation to } \\
\text { environmental changes (Padedda et al. 2012), influence of } \\
\text { drought and abiotic factors (Sangiorgio et al. 2006). }\end{array}$ \\
\hline Inventory & $\begin{array}{l}\text { Papers presenting inventories and records of species composition, } \\
\text { and results of field surveys introducing a set of species occurring } \\
\text { in wetland sites. This research theme also included papers on } \\
\text { presence records or preliminary inventories of invasive alien } \\
\text { plant species (IAS), and papers that examining the assemblage } \\
\text { of plant species and the ground cover that they provide, without } \\
\text { specific reference to particular taxa, life forms, structure, or } \\
\text { spatial extent. }\end{array}$ & $\begin{array}{l}\text { Floras of specific areas (De Martis and Loi 1989; Fumanti and } \\
\text { Cavacini 2002), regional checklist of native or alien vascular } \\
\text { plants (Mayoral et al. 2018; Desfayes 2008), phytoplankton, } \\
\text { potentially toxic dinoflagellates, (Sannio et al. 1996), bryologi- } \\
\text { cal flora (Cogoni et al. 2004). }\end{array}$ \\
\hline Palaeobotany & $\begin{array}{l}\text { Papers focusing on the recovery and identification of plant remains } \\
\text { from wetlands, including the evolutionary history of plants. } \\
\text { Papers from the field of palynology, which studies fossilised and } \\
\text { extant spores and pollen from wetlands, were also included here. }\end{array}$ & $\begin{array}{l}\text { Palynological (Buosi et al. 2013) and archaeobotanical investiga- } \\
\text { tions (Ucchesu et al. 2017), vegetation reconstructions (Buosi } \\
\text { et al. 2017). }\end{array}$ \\
\hline Taxonomy & $\begin{array}{l}\text { Papers naming and describing plant species, as well as identifying } \\
\text { and classifying wetland plants. }\end{array}$ & New wetland taxa (Alfinito et al. 2000, Bacchetta et al. 2010). \\
\hline
\end{tabular}

\section{Results}

\section{Research Trends within Plant Groups}

Around $64 \%$ of the 202 retained papers focused on vascular plants, followed by $28 \%$ on algae, and the remaining $6 \%$ on bryophytes (Fig. 2a). Only two papers $(\sim 1 \%)$ considered the interaction between vascular plants and algae (Boix et al. 2017), and vascular plants and bryophytes (Bagella et al. 2016), both in temporary wetlands.

The first contribution to the modern literature on bryophytes in wetland habitats focused on inventorying the already known species in Sardinia (Cortini Pedrotti 1980) (Fig. 2b). Only during the last two decades, studies investigating the ecology of bryophytes began to appear, becoming the predominant research theme in the last decade. For algae, the first contribution to modern literature dates back to 1970s, with the theme witnessing an increasing interest in time. Vascular plants were the object of modern literature since the 1960s and represented the most studied group in almost all decades, except for the 1990s, when algae were the most dominant subject. Vascular plants were topics in all research themes and were the single theme in palaeobotanical papers (Fig. $2 c)$. The algae group was investigated under all the rest of research themes, except for palaeobotany, and most of studies were focused on their ecology. Conservation aspects have interested researchers of all three plant groups, even though more focus was on vascular plants, and the only one paper about the conservation of bryophytes was also dealt with the vascular plant group (Bagella et al. 2016). No modern papers on bryophyte taxonomy were found (Fig. 2c).

As regards wetland types, papers about the algae focused mainly on marine and coastal, and then on human-made ones (Fig. 2d). Bryophytes were mostly studied in inland wetlands, while vascular plants mainly in marine and coastal, and then in inland wetlands, but rarely in human-made ones (Fig. 2d).

Of the 376 total georeferenced investigated locations (Fig. 1, see Supplementary Information 2), ca $61 \%$ are inside a protected area. Of them, 221 are included inside the Natura 2000 network, 36 in parks and 34 in Ramsar sites. However, it is worth noting that most Ramsar sites and national and regional parks are also included in the Natura 2000 network (Fig. 1).

\section{Research Trends within Research Themes}

The review of the modern literature on wetland plants in Sardinia during the last 60 years highlighted a rising trend from nine and 10 respectively in the 1960's and 1970's (mostly inventories) to 28 in the 1980's (see Fig. 3a). During this decade, studies on ecology and taxonomy become more widespread, although inventories continued to predominate. The number of published papers fell during the 1990's, with only 15 papers related to wetland plants and most of them reporting (again) on inventories. With the beginning of the 2000s, wetland plant studies increased to 44 , including four research 
Fig. 2 (a) Paper categorisation by plant group; (b) paper temporal trend by plant group; (c) pie chart showing the distribution of papers on each plant group by research themes; and (d) paper number by wetland types. The two papers that considered the interaction between vascular plants and algae (Boix et al. 2017) and vascular plants and bryophytes (Bagella et al. 2016), were not included here (a)

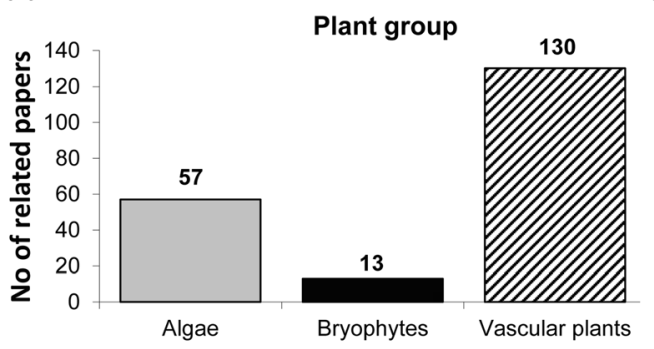

(b)

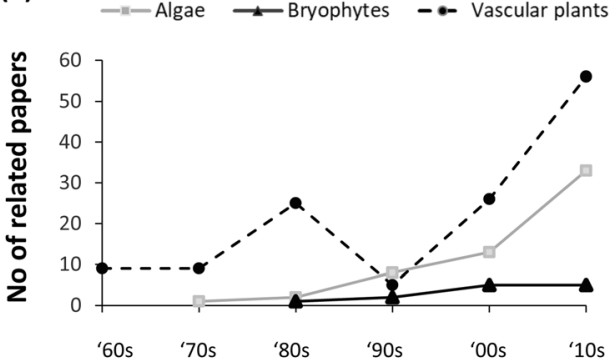

(c)

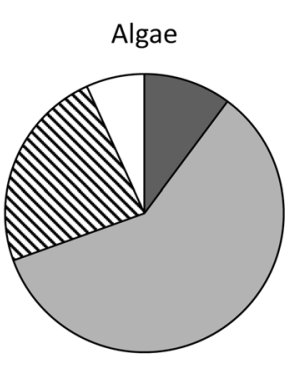

(d)

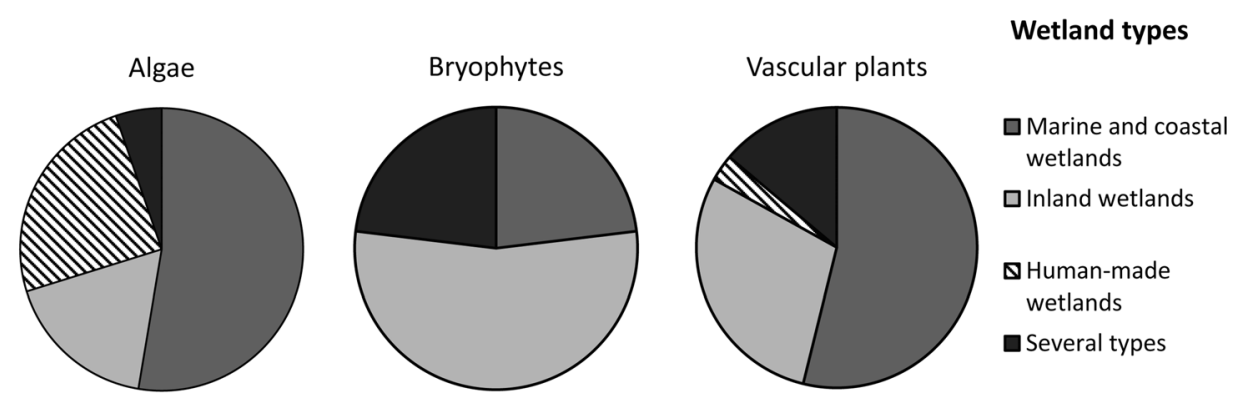

Research themes

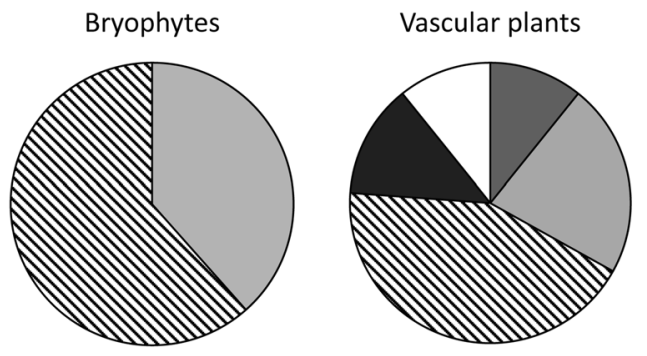

$\square$ Conservation

$\square$ Ecology

$\Delta$ Inventory

- Palaeobotany

$\square$ Taxonomy themes (no palaeobotany). However, the main efforts were again focused on inventories and increasingly on ecology, and marginally on taxonomy and conservation. In the second decade of the 2000 s, the number of published papers continued to increase (96), and a diversification of studies, including the three plant groups and all research themes, was observed. For the first time, the main research focus was on ecology, followed by conservation and palaeobotany. In total, the highest contribution was provided by inventories (77 papers), followed by ecology (69). Less consideration was given to conservation (21), taxonomy (18), and palaeobotany (17).

\section{Research Trends within Wetland Types}

A great number of papers (103) were about coastal wetlands around the entire Sardinia and its surrounding islands (Fig. 1). Detailed type 'Coastal brackish/saline lagoons (J)' was the most investigated (93 papers; see Table 2 for further details about each plant group). Papers on inland wetlands began to be published in the 1970's; their frequency increased in the 2000s and peaked in the 2010s, when it almost equalled the number of works on coastal wetlands. Human-made wetlands were of less interest and among these, Type ' 6 Water storage areas' was the most studied (16 papers) - a relatively constant trend over the time (Fig. 3b).

\section{Discussion}

\section{Research Trends within Plant Groups: Towards a more Effective Conservation}

A vast modern literature about Sardinian wetland plants has been amassed since the 1960s. However, despite their ecological and functional importance and the increasing number of works that have highlighted it, wetlands plants are overlooked in broad-scale investigations, which can lead to inaccurate or to conflicting assessments of their current spatial patterns and 
Fig. 3 Paper temporal trend by (a) research themes involved and (b) main wetland type (a)

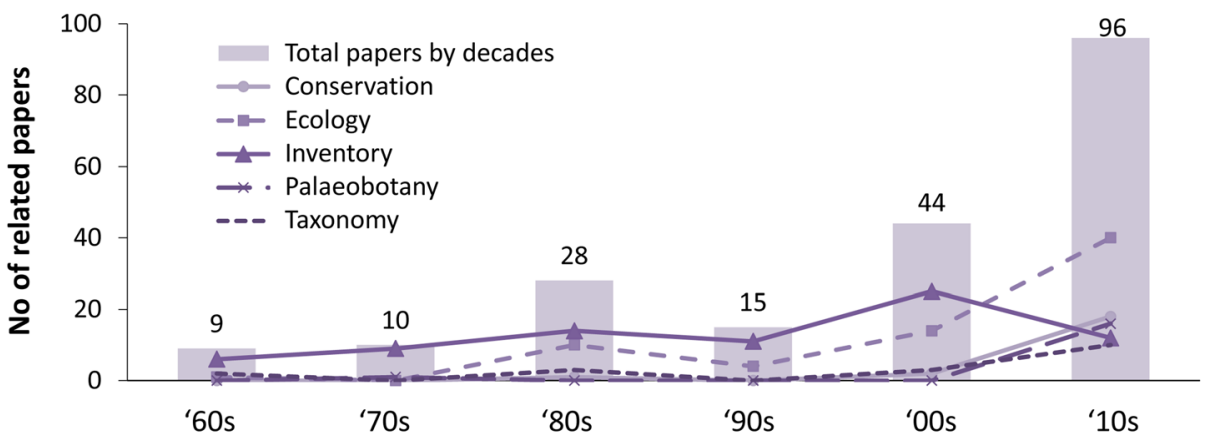

(b)

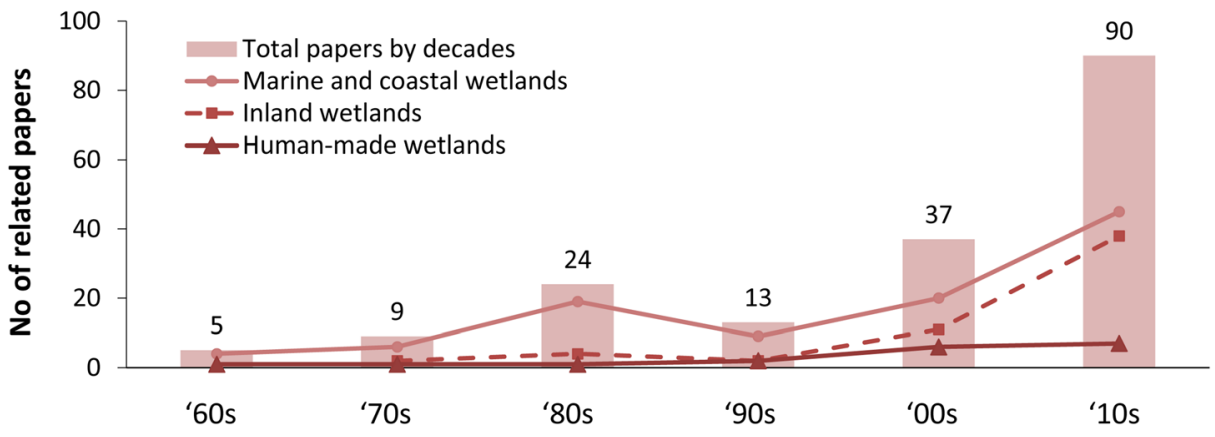

existence at global (Alahuhta et al. 2017), and regional levels (Bolpagni et al. 2018). In the case of Sardinia, a large and representative example of Mediterranean wetlands, there are several gaps. One, highlighted by this review, is the discrepancy between the number of research papers on vascular plants and those of papers focusing on the other two plant groups. The scarce number of studies about bryophytes in wet Mediterranean habitats looks incongruent with the high number of species, second only to vascular plants, and their high economic, ecological, and conservation value (Hodgetts et al. 2019), as well as their contribution to the total biomass of wetlands (Fuselier et al. 2012). This could be explained by a lack of intense efforts to identify these groups. For example, in the case of bryophytes, the number of species is difficult to estimate because most of specific studies are confined to only a fraction of those which have been described (Hallingbäck and Hodgetts 2000). Despite some exceptions, such as bogs, fens, and peat swamps, bryophytes and, in general, all cryptogams are globally overlooked in most environments. Bryophytes were proved to have a significant value as indicators of biological effects of climate change (Gignac 2001; Désamoré et al. 2012), especially in the Mediterranean areas (Cogoni et al. 2016), and are one of most promising life-forms which could assist in monitoring and remediating heavy-metal polluted soils and wetlands (Schintu et al. 2005; Rahman et al. 2016). However, there is a need for simple and appropriate experimental models that would enable the researchers to dissect biochemically and genetically the response of less complex plants to environmental stress (Oliver et al. 2000).
Another gap concerns algal component knowledge, even though algae are more largely studied than bryophytes. Despite their importance for understanding ecosystem processes, conservation, and water quality, the difficulties in studying them are often related to the inherent problem of small organisms with morphologies which are hard to be distinguished without research-grade microscopes and taxonomic expertise in phycology (Manoylov 2014). A recent review (Bolpagni et al. 2019) highlighted the same issue for the algal component of standing-water ecosystems, where primary producers (including algae) were inadequately investigated. The algal component exhibits a high diversity in widely different environmental conditions and many are specifically dependent on wetlands (Alfinito and Iberite 2013). Studies on algae were mostly concentrated on various lineages of phytoplankton, such as dinoflagellates, diatoms, haptophytes, and cryptophytes. Most papers analysed the phytoplankton component of coastal lagoons (e.g. Fiocca et al. 1996; De Miranda et al. 2005) and, also, of ephemeral/temporary ponds (e.g. Alfinito and Iberite 2013) and lakes (e.g. Sechi and Cossu 1985). Such studies often investigated and inventoried harmful algal species (HAS) and the environmental factors that affect their blooming (e.g. Sannio et al. 1996; Padedda et al. 2012). Ecological studies generally correlated the abundance, presence, or fluctuation of algae conditions with physical and chemical water gradients (De Miranda et al. 2005; Padedda et al. 2012). There are few papers on algal conservation, despite their usefulness for the evaluation of water and, consequently, for wetland conservation and effective monitoring 
Table 2 Number of papers by wetland types mentioned in the analysed papers according to the Ramsar classification (Ramsar Convention Secretariat 2010), subdivided by plant group and themes. Categorisation was based on three main types: marine and coastal, inland, and human-made wetlands, which were hierarchically subdivided into more detailed wetland types. Some papers were classified under 'several types' because they presented researches on several or unspecified wetland types

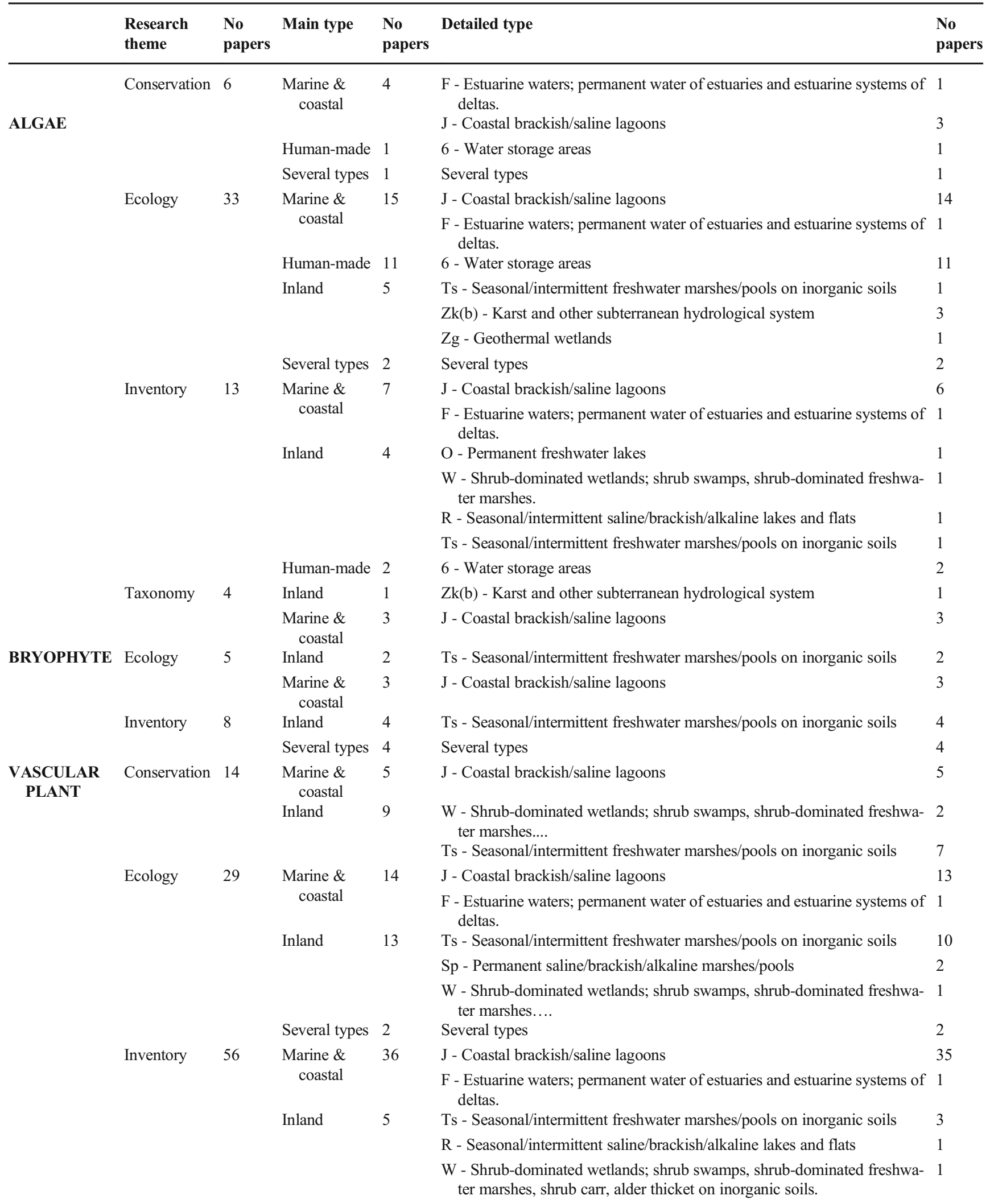


Table 2 (continued)

\begin{tabular}{|c|c|c|c|c|c|}
\hline $\begin{array}{l}\text { Research } \\
\text { theme }\end{array}$ & $\begin{array}{l}\text { No } \\
\text { papers }\end{array}$ & Main type & $\begin{array}{l}\text { No } \\
\text { papers }\end{array}$ & Detailed type & $\begin{array}{l}\text { No } \\
\text { papers }\end{array}$ \\
\hline \multirow{7}{*}{ Palaeobotany } & \multirow{7}{*}{17} & \multirow[t]{2}{*}{ Human-made } & \multirow[t]{2}{*}{3} & 6 - Water storage areas & 1 \\
\hline & & & & 7 - Excavations; gravel/brick/clay pits; borrow pits, mining pools. & 2 \\
\hline & & Several types & 12 & Several types & 12 \\
\hline & & \multirow[t]{2}{*}{$\begin{array}{r}\text { Marine \& } \\
\text { coastal }\end{array}$} & \multirow[t]{2}{*}{12} & $\begin{array}{l}\text { F - Estuarine waters; permanent water of estuaries and estuarine systems of } \\
\text { deltas }\end{array}$ & 1 \\
\hline & & & & $\mathrm{J}$ - Coastal brackish/saline lagoons & 11 \\
\hline & & \multirow[t]{2}{*}{ Inland } & \multirow[t]{2}{*}{3} & $\mathrm{P}$ - Seasonal/intermittent freshwater lakes & 2 \\
\hline & & & & Sp - Permanent saline/brackish/alkaline marshes/pools & 1 \\
\hline & & Several types & 2 & Several types & 2 \\
\hline \multirow[t]{7}{*}{ Taxonomy } & \multirow[t]{7}{*}{14} & \multirow[t]{2}{*}{$\begin{array}{r}\text { Marine \& } \\
\text { coastal }\end{array}$} & \multirow[t]{2}{*}{3} & $\begin{array}{l}\text { F - Estuarine waters; permanent water of estuaries and estuarine systems of } \\
\text { deltas. }\end{array}$ & 1 \\
\hline & & & & $\mathrm{J}$ - Coastal brackish/saline lagoons & 2 \\
\hline & & \multirow[t]{3}{*}{ Inland } & \multirow[t]{3}{*}{8} & Sp - Permanent saline/brackish/alkaline marshes/pools & 2 \\
\hline & & & & Ts - Seasonal/intermittent freshwater marshes/pools on inorganic soils & 3 \\
\hline & & & & $\begin{array}{l}\text { W - Shrub-dominated wetlands; shrub swamps, shrub-dominated freshwa- } \\
\text { ter marshes }\end{array}$ & 3 \\
\hline & & Human-made & 1 & 6 - Water storage areas & 1 \\
\hline & & Several types & 2 & Several types & 2 \\
\hline
\end{tabular}

techniques (Lai et al. 2010; Manzano et al. 2019). Some algae - such as the oceanic phytoplankton, the seaweeds along almost every coastline in the world, or the algae of lakes and rivers - seem abundant, giving the general impression of commonness for the entire group (Brodie et al. 2009). However, many algae are restricted in their distribution and vulnerable due to rising levels of adverse stressors, including climate change, colonisation by alien species, eutrophication, and increases in harmful phytoplankton species (Satta et al. 2017). A recent paper on Sardinian charophytes (Becker 2019), defined as 'terra incognita', demonstrated that nine of the 26 taxa known in Sardinia are very rare and endangered. Few countries protect algae legally. Australia has threatened species legislation. In the Habitats Directive (Council of the European Communities 1992), two species of red algae, Lithothamnion corallioides and Phymatolithon calcareum, are listed in relation to their possible exploitation (Brodie et al. 2009) and habitat 3140 'hard oligo-mesotrophic waters with benthic vegetation of Chara spp.' is mostly characterised by charophytes. Further studies about the algae group and, in particular, endangered and characteristic groups such as phytoplankton and charophytes, are therefore, also needed for a more effective wetland management and conservation.

Despite the predominance of vascular plant studies, due to their high representativeness within the Plantae Kingdom and their functional and conservation relevance, there is a need for more research on this group, especially with more integrative and innovative approaches. For instance, works analysing the co-occurrence of or even interactions between two or all three analysed plant groups, were unfortunately rare in Sardinia, even if the new decade has promisingly started with an attempt in this sense (Marignani et al. 2020). Global examples focus on old-growth forests (e.g. Dittrich et al. 2014) and some wetland types, such as Sphagnum peatlands (Koenig et al. 2015) or temporarily inundated soils of arable land in Central Europe (Popiela 2005). An increase of interdisciplinary and interspecific approaches might be pursued in the next decades to enhance knowledge on community inventory and possible interactions between groups. Even though the effectiveness of cross-taxon congruence in addressing conservation programmes and setting out priority areas for conservation has been widely debated (Bagella 2014), understanding patterns of interaction between taxonomic groups and their application in conservation and restoration programmes is a key future direction (Marazzi et al. 2019; Marignani et al. 2020). The rapid environmental changes in the current Anthropocene era need to be frequently recorded, starting with the largely reported information regarding, for instance, the inventories of vascular plants. Comparisons during a relatively short time span have often uncovered significant vegetation changes (e.g. Sciandrello et al. 2021), such as local extinction or colonisation of exotic taxa, which are mainly caused by humanrelated factors. Monitoring and evaluating these changes, could be key issues to the conservation of vascular plants and other living organisms associated with them.

\section{Research Trends within Research Themes}

Regarding the investigated research themes, efforts were concentrated mainly on inventories. If regularly updated, the 
exploration of species presence provides crucial information, although this alone does not directly contribute to the understanding of an ecosystem's functioning (Chelli et al. 2019). The need to fill such important information gaps was, however, evident, and as such, there was an important increase in research on ecology, most specifically on the environmental factors which influence the presence, distribution, and abundance of wetlands plants.

Compared to the above-mentioned research themes, the number of conservation papers appears surprisingly lower than expected. Though conservation is certainly a crucial research theme in biodiversity studies, the special interest in this issue is relatively recent around the world (Godet and Devictor 2018). This trend also applies to Sardinian wetland plants, whose conservation was not a topic of research until the end of 1990s and became the second major theme in the previous decade. However, we must acknowledge that our search may have missed information reported in the 'grey literature', such as technical project reports which often address this research theme.

The number of papers based on palaeobotany increased significantly during the previous decade. Wetland soils are particularly able to preserve remains in conditions of oxygen exclusion and constant stratification. For instance, the recovery of several Punic artefacts that have been brought to light during underwater explorations has enabled the gathering of archaeological and geomorphological data and the investigation of pollen, spores and archaeobotanical contents such as seeds and fruits (Buosi et al. 2017; Ucchesu et al. 2017). Palaeobotany also allows the identification of the ways in which prehistoric humans interacted with marine and inland water environments. Humans have often established their socio-economic settlements around wetlands. Therefore, investigating the historical exploitation of marine and inland waters resources is crucial. For example, the Sardinian wetlands were used as source of food and material for traditional handicrafts and for mitigating natural hazards (Melis et al. 2012; Pascucci et al. 2018). However, considering the central role of wetlands in many civilisations, e.g. the ancient Babylonians and Egyptians ones, further investigations have also potential applications areas, such as the cultural and environmental valorisation and sustainable use of wetlands. Moreover, palaeobotanical studies are the main tool for enhancing knowledge of former native vegetation under different environmental conditions, and they also provide a wider perspective in the debate about future climate changes.

Finally, the fact that the number of taxonomical studies is increasing, indicates the wide diversity of organisms, plants in particular, and the high possibility of finding new wetland species in the next years; this could be particularly true for bryophytes and algae groups. Updating of inventories due to taxonomic discoveries may enhance conservation outputs based on ecological and environmental analyses that correlate the plant distribution patterns with the increasing available data on different environmental measures. In this sense, a new series of publications on collaborative national inventories to improve plant conservation, is promisingly under way (e.g. Rivieccio et al. 2020; Ravera et al. 2020).

\section{Gaps and Challenges within Wetland Types}

Our observations suggest that the studies were well distributed around the entire island and many different wetland types were covered. We detected a higher concentration of studies in protected areas and a greater focus on marine and coastal wetlands compared to inland or human-made ones. Coastal and marine wetlands are of high local and landscape value for related activities (aquaculture, tourism), a substantial number of beneficial ecosystem services (Engle 2011), and for being efficient carbon sinks (Ramsar Convention Secretariat 2010). They include lagoons, estuaries, and saltmarshes, which cover bigger surfaces and are also easy to reach. Therefore, the high concentration of research in these areas is not surprising. Although they are the most investigated type and many are protected as Ramsar sites, parks and included in the Natura 2000 network, they continue to be threatened in the Mediterranean and in most of coastal regions around of the world, mainly due to the great loss of areas through drainage and other hydrological alterations, firstly for agricultural reasons and, more recently, for housing, industry, and tourism development (Leberger et al. 2020). The efficiency of protected area designation in reducing land-taking practices have been proven in Sardinia. However, conflicts between conservation measures and traditional land uses need managing within planning processes (Lai et al. 2017), and the allocation of species-specific funding is also necessary in some cases to support plant conservation and related services (Zacharias et al. 2007; Bagella et al. 2013; Ferrarini et al. 2020).

Regarding inland wetlands, the most investigated were the 'Ts- Seasonal/intermittent freshwater marshes/pools on inorganic soils', represented in Sardinia mainly by temporary ponds. These are typical of seasonal climates such as the semi-arid and Mediterranean-type regions of South and North America, Australia, South Africa and Europe (Zacharias et al. 2007, and references therein), although similar ephemeral conditions occur in all regions, e.g. the tropical and subtropical pools on rock outcrops and inselbergs (Deil 2005). Ephemeral wetland conditions are also present along the shores of permanent lakes and rivers, and are predominant where catchments areas are very large, such as the floodplains of rivers in the Amazon Basin (Ricaurte et al. 2012). In the Mediterranean Basin, temporary ponds are irreplaceable environments which host groups differing from those of permanent ponds, and, in some cases, highly specialised species of great conservation importance. Their elevated biodiversity has 
been attributed to their high spatio-temporal variability (i.e., hydroperiod or duration of inundation; Van den Broeck et al. 2015) and to a typical small-scale zonation (Cogoni et al. 2016). However, the number of scientific publications on temporary ponds is not proportional to their ecological importance (Zacharias et al. 2007; Bagella et al. 2016; Boix et al. 2017), although it has increased significantly in Sardinia, but only in recent years. Globally, an unrefined search on Web of Science for works mentioning in the title the various names for temporary aquatic habitat as reported in Zacharias et al. (2007), has revealed that more than $80 \%$ of the papers focused on European (43\%) and US (38\%) ephemeral wetlands, which suggests possible knowledge gaps for other territories, such as Northern Africa and Southern America (see Fig. 1A, in Supplementary Information 3). The main issue for studying temporary ponds comes from their ephemeral nature and small size, which makes their accurate quantification and the recognition of their environmental values difficult. Although temporary ponds have been recognised as a wetland type of international importance by the Ramsar Convention (Ramsar Convention Secretariat 2010), and included in the Natura 2000 network, their continued loss and impairment is still occurring in most Mediterranean countries (Ruiz 2008; Becker 2019), mainly due to anthropogenic pressures, such as intensification of agriculture or land abandonment, overgrazing, hydrologic perturbations, touristic/recreational uses, fires and introduction of exotic species (Zacharias et al. 2007). In addition to the already mentioned threats, the increasing aridity trend projected for the Mediterranean areas in the climate change scenarios will surely trigger new waves of wetland demise (Barredo et al. 2016), hence, conservation efforts become even more critical. However, traditional land use is a key factor for the conservation of temporary ponds. It is widely documented that plant diversity in this wetland type has been maintained over the centuries by extensive human activities, and abandonment has negative effects on plant assemblage. For instance, moderate disturbances by cattle are important for plants, because they help maintain diverse communities (Marty 2015), to reduce transpiration by removing biomass and lowering infiltration rate through trampling, and to control the colonisation of shrubs and opportunistic and allochthonous species (Pyke and Marty 2005; Ferchichi-Ben Jamaa et al. 2014).

Our search shows that human-made wetlands were less considered, and most papers focused on '6- Water storage areas'. Studies on the abundances and dynamic effects of eutrophication were carried out, especially regarding the algae group, due to the need to increase the knowledge of these aspects in each reservoir, whose use could affect human and animal health. Because in Sardinia more than $90 \%$ of the drinking water originates from artificial lakes, which are generally eutrophic (Sechi and Cossu 1985, Lugliè et al. 2001), knowledge in this respect must be continuously acquired and also consider European (e.g. WFD 2000/60/EC) and regional (e.g. L.R. n. 19/2006) regulations. Several studies have demonstrated that the main triggers for the development of algal blooms are nutrients, specifically N and P (Mariani et al. 2015; Padedda et al. 2017); however, consequences of such events have been linked mostly to human health-related issues and seldom to potential ones such as species disappearance or loss of environmental quality. This is also an effect of a lack of information about the other plant groups, namely vascular plants and bryophytes, in anthropogenic wetlands. Examples to be followed are those of China (Wang et al. 2019), Brazil (Alves-da-Silva et al. 2014) and Italy (Croce 2015), where plant diversity gradients and comparisons between artificial and natural freshwater environments have been carried out.

\section{Conclusions}

This paper represents one of first attempts to describe the extensive work that has been hitherto carried out to enhance knowledge of plants in a widely representative set of Mediterranean wetlands. Trends within three different plant groups revealed strengths and gaps at different levels and for different research themes. Efforts towards the integration and implementation of the existing information increased during the previous decade; nevertheless, updating the existing inventories, together with applying new methods and approaches, is a future objective that is hard but not impossible to attain. Inventories and taxonomic delimitations are still basic issues which need to be expanded through the inclusion of uninvestigated sites, regardless of their protection level, and to be constantly updated in order to monitor human-related changes and effects. Conservation is a relatively recent but increasing topic that may be enriched, for instance, through the inclusion of algal and other neglected taxa in red lists and policies. Implementing a protected areas network and its connectivity through ecological corridors may be another crucial future objective. There are examples where active conservation measures have contributed positively towards the slowing down of wetlands' depletion; for these, biodiversity data coverage needs to be ensured, regularly updated, and extended across sites regardless of their protection level. Studies on ecology and multidisciplinary cooperation among experts may provide important tools, such as finding interactions between taxonomic groups, which can support wise and more effective conservation measures. All this information may be incorporated into management plans which also take into account the local socio-economic context to reduce possible conflicts and increase the conservation effectiveness.

Supplementary Information The online version contains supplementary material available at https://doi.org/10.1007/s13157-021-01464-z. 
Acknowledgments Women botanist's participation has in general tended to remain silent in the scientific world. However, we found in this study that $53 \%$ of the total papers were first authored by women, highlighting their important contribution to Sardinian scientific community. We would like to express sincerely thanks to all of them. Comments from three anonymous reviewers considerably improved an earlier version of this manuscript.

Authors' Contributions Study conception and design were performed by ACL and MF. Data were collected by ACL and data analysis was performed by ACL and MF. The first draft of the manuscript was written by ACL and revised by MF, AC and GB. This study was supervised by GB. All authors read and approved the final manuscript.

Funding Open access funding provided by Università degli Studi di Cagliari within the CRUI-CARE Agreement. This research was supported by the Mediterranean Island Wetlands project (MedisWet) funded by MAVA Foundation.

Code Availability Not applicable.

\section{Declarations}

Conflicts of Interest/Competing Interests The authors have no conflicts of interest.

Ethics Approval Not applicable.

Consent to Participate Not applicable.

Consent for Publication Not applicable.

Availability of Data and Material Data are provided in Supplementary material.

Open Access This article is licensed under a Creative Commons Attribution 4.0 International License, which permits use, sharing, adaptation, distribution and reproduction in any medium or format, as long as you give appropriate credit to the original author(s) and the source, provide a link to the Creative Commons licence, and indicate if changes were made. The images or other third party material in this article are included in the article's Creative Commons licence, unless indicated otherwise in a credit line to the material. If material is not included in the article's Creative Commons licence and your intended use is not permitted by statutory regulation or exceeds the permitted use, you will need to obtain permission directly from the copyright holder. To view a copy of this licence, visit http://creativecommons.org/licenses/by/4.0/.

\section{References}

Alahuhta J, Kosten S, Akasaka M, Auderset D, Azzella MM, Bolpagni R, Bove CP, Chambers PA, Chappuis E, Clayton J, de Winton M, Ecke F, Gacia E, Gecheva G, Grillas P, Hauxwell J, Hellsten S, Hjort J, Hoyer MV, Ilg C, Kolada A, Kuoppala M, Lauridsen T, Li EH, Lukács BA, Mjelde M, Mikulyuk A, Mormul RP, Nishihiro J, Oertli B, Rhazi L, Rhazi M, Sass L, Schranz C, Søndergaard M, Yamanouchi T, Yu Q, Wang H, Willby N, Zhang XK, Heino J (2017) Global variation in the beta diversity of lake macrophytes is driven by environmental heterogeneity rather than latitude.
Journal of Biogeography 44:1758-1769. https://doi.org/10.1111/ jbi. 12978

Aleffi M, Tacchi R, Poponessi S (2020) New checklist of the bryophytes of Italy. Cryptogamie Bryologie 41:147-195. https://doi.org/10. 5252/cryptogamie-bryologie2020v41a13

Alfinito S, Cavacini P, Fumanti B (2000) Contributo alla conoscenza della flora algale di acqua dolce della Sardegna: 24 taxa nuovi per l'Italia provenienti dal Sistema del Molentargius (Cagliari). Boll Soc Sarda Sci Nat 32:129-141

Alfinito S, Iberite M (2013) The freshwater algal flora of the "Giara di Gesturi" (Sardinia, Italy). Annali di Botanica 3:51-85. https://doi. org/10.4462/annbotrm-10242

Alves-da-Silva SC, Bona C, de Chiara Moço MC, Cervi AC (2014) Floristic survey and species richness of aquatic macrophytes in water supply reservoirs. Check list 10:1324-1330. https://doi.org/10. $15560 / 10.6 .1324$

Arisci A, De Waele J, Di Gregorio F, Ferrucci I, Follesa R (2003) Integrated, sustainable touristic development of the karstic coastline of SW Sardinia. Journal of Coastal Conservation 9:81-90. https:// doi.org/10.1652/1400-0350(2003)009[0081:ISTDOT]2.0.CO;2

Bacchetta G, Brullo S, Salmeri C (2010) Hypericum scruglii sp nov (Guttiferae) from Sardinia. Nordic Journal of Botany 28:469-474. https://doi.org/10.1111/j.1756-1051.2009.00736.x

Bartolucci F, Peruzzi L, Galasso G, Albano A, Alessandrini A, Ardenghi NMG, Astuti G, Bacchetta G, Ballelli S, Banfi E, Barberis G, Bernardo L, Bouvet D, Bovio M, Cecchi L, di Pietro R, Domina G, Fascetti S, Fenu G, Festi F, Foggi B, Gallo L, Gottschlich G, Gubellini L, Iamonico D, Iberite M, Jiménez-Mejías P, Lattanzi E, Marchetti D, Martinetto E, Masin RR, Medagli P, Passalacqua NG, Peccenini S, Pennesi R, Pierini B, Poldini L, Prosser F, Raimondo FM, Roma-Marzio F, Rosati L, Santangelo A, Scoppola A, Scortegagna S, Selvaggi A, Selvi F, Soldano A, Stinca A, Wagensommer RP, Wilhalm T, Conti F (2018) An updated checklist of the vascular flora native to Italy. Plant Biosyst 152:179-303. https://doi.org/10.1080/11263504.2017.1419996

Bagella S (2014) Does cross-taxon analysis show similarity in diversity patterns between vascular plants and bryophytes? Some answers from a literature review. Compt Rendus Biol 337:276-282. https:// doi.org/10.1016/j.crvi.2014.01.003

Bagella S, Caria MC, Filigheddu R (2013) Gap analysis revealed a low efficiency of Natura 2000 network for the conservation of endemic species in Mediterranean temporary freshwater habitats. Plant Biosyst 147:1092-1094. https://doi.org/10.1080/11263504.2013. 860055

Bagella S, Gascón S, Filigheddu R, Cogoni A, Boix D (2016) Mediterranean temporary ponds: new challenges from a neglected habitat. Hydrobiologia 782:1-10. https://doi.org/10.1007/s10750016-2962-9

Bagella S, Caria MC, Farris E, Filigheddu R (2009) Spatial-time variability and conservation relevance of plant communities in Mediterranean temporary wet habitats: a case study in Sardinia (Italy). Plant Biosyst 143:435-442. https://doi.org/10.1080/ 11263500903187068

Barredo JI, Caudullo G, Dosio A (2016) Mediterranean habitat loss under future climate conditions: assessing impacts on the Natura 2000 protected area network. Applied Geography 75:83-92. https://doi. org/10.1016/j.apgeog.2016.08.003

Becker R (2019) The Characeae (Charales, Charophyceae) of Sardinia (Italy): habitats, distribution and conservation. Webbia 74:83-101. https://doi.org/10.1080/00837792.2019.1607497

Boix D, Caria MC, Gascón S, Mariani MA, Sala J, Ruhí A, Compte J, Bagella S (2017) Contrasting intra-annual patterns of six biotic groups with different dispersal mode and ability in Mediterranean temporary ponds. Marine and Freshwater Research 68:1044-1060. https://doi.org/10.1071/MF15435 
Bolpagni R, Laini A, Stanzani C, Chiarucci A (2018) Aquatic plant diversity in Italy: distribution drivers and strategic conservation actions. Frontiers in Plant Science 9:116. https://doi.org/10.3389/fpls. 2018.00116

Bolpagni R, Poikane S, Laini A, Bagella S, Bartoli M, Cantonati M (2019) Ecological and conservation value of small standing-water ecosystems: a systematic review of current knowledge and future challenges. Water 11:402. https://doi.org/10.3390/w11030402

Brodie J, Andersen RA, Kawachi M, Millar AJ (2009) Endangered algal species and how to protect them. Phycologia 48:423-438

Brundu G, Azzella MM, Blasi C, Camarda I, Iberite M, Celesti-Grapow L (2013) The silent invasion of Eichhornia crassipes (Mart.) Solms. In Italy. Plant Biosyst 147:1120-1127. https://doi.org/10.1080/ 11263504.2013.861536

Buosi C, Pittau P, Del Rio M, Mureddu D, Locci MC (2013) A palynological investigation of funerary urn contents from the Roman Imperial age necropolis in Sardinia (Italy). Palynology 37:130 142. https://doi.org/10.1080/01916122.2012.718995

Buosi C, Del Rio M, Orrù P, Pittau P, Scanu GG, Solinas E (2017) Sea level changes and past vegetation in the Punic period (5th-4th century BC): archaeological geomorphological and palaeobotanical indicators (South Sardinia-West Mediterranean Sea). Quaternary International 439:141-157. https://doi.org/10.1016/j.quaint.2016. 07.005

Cavalier-Smith T (1998) A revised six-kingdom system of life. Biological Reviews 73:203-266. https://doi.org/10.1111/j.1469-185X.1998. tb00030.x

Chelli S, Marignani M, Barni E, Petraglia A, Puglielli G, Wellstein C, Acosta ATR, Bolpagni R, Bragazza L, Campetella G, Chiarucci A, Conti L, Nascimbene J, Orsenigo S, Pierce S, Ricotta C, Tardella FM, Abeli T, Aronne G, Bacaro G, Bagella S, Benesperi R, Bernareggi G, Bonanomi G, Bricca A, Brusa G, Buffa G, Burrascano S, Caccianiga M, Calabrese V, Canullo R, Carbognani M, Carboni M, Carranza ML, Catorci A, Ciccarelli D, Citterio S, Cutini M, Dalle Fratte M, de Micco V, del Vecchio S, di Martino L, di Musciano M, Fantinato E, Filigheddu R, Frattaroli AR, Gentili R, Gerdol R, Giarrizzo E, Giordani P, Gratani L, Incerti G, Lussu M, Mazzoleni S, Mondoni A, Montagnani C, Montagnoli A, Paura B, Petruzzellis F, Pisanu S, Rossi G, Sgarbi E, Simonetti E, Siniscalco C, Slaviero A, Stanisci A, Stinca A, Tomaselli M, Cerabolini BEL (2019) Plant-environment interactions through a functional traits perspective: a review of Italian studies. Plant Biosyst 153:853869. https://doi.org/10.1080/11263504.2018.1559250

Cheng Y, Zha Y, Tong C, Hu M, Du D, Fan Y, Chen L (2020) Plant population dynamics in a degraded coastal wetland and implications for the carbon cycle. Wetlands 40:1617-1625. https://doi.org/10. 1007/s13157-020-01268-7

Cogoni A, Aleffi M, Scrugli A (1999) Sardinia's bryological flora: the state of knowledge and chorological considerations. Webbia 53: 381-392. https://doi.org/10.1080/00837792.1999.10670666

Cogoni A, Filippino G, Marignani M (2016) Small-scale pattern of bryoflora in Mediterranean temporary ponds: hints for monitoring. Hydrobiologia 782:81-95. https://doi.org/10.1007/s10750-0152635-0

Cogoni A, Flore F, Adamo C, Scrugli A (2004) Bryological flora of the Giara di Gesturi tableland (southern-Central Sardinia). BraunBlanquetia 34:51-58

Cogoni A, Flore F, Adamo C, Lai R, Scrugli A (2006) Ecology of bryophytes of damp areas at Giara di Gesturi (southern Central Sardinia). Bocconea 19:65-76

Cogoni A, Scrugli A, Cortis P (2009) Bryophyte flora of some temporary pools in Sardinia and Corsica. Plant Biosyst 143:97-103. https://doi. org/10.1080/11263500903220190

Cortini Pedrotti C (1980) Prodromo dei muschi della Sardegna. Lav Soc Ital Biogeogr 8:139-169
Council of the European Communities (1992) Council Directive 92/43/ EEC of 21 May 1992 on the conservation of natural habitats and of wild fauna and flora Official Journal of the European Communities. L206. pp 7-50

Croce A (2015) Vascular flora of eight water reservoir areas in southern Italy. Check List 11:1593

Cronk JK, Fennessy MS (2016) Wetland plants: biology and ecology CRC press

Cuena A, Fois M, Fenu G, Bacchetta G (2013) Schede per una lista rossa della flora vascolare e crittogamica italiana: Romulea bocchierii Frignani \& Iriti. Inform Bot Ital 45:319-390

Dalla Vecchia A, Villa P, Bolpagni R (2020) Functional traits in macrophyte studies: current trends and future research agenda. Aquat bot: 103290. 167:103290. https://doi.org/10.1016/j.aquabot.2020. 103290

Davidson NC (2014) How much wetland has the world lost? Long-term and recent trends in global wetland area. Marine and Freshwater Research 65:934-941. https://doi.org/10.1071/MF14173

Deane DC, Fordham DA, He F, Bradshaw CJ (2016) Diversity patterns of seasonal wetland plant communities mainly driven by rare terrestrial species. Biodiversity and Conservation 25:1569-1585. https:// doi.org/10.1007/s10531-016-1139-1

De Martis B, Loi MC (1989) La flora della Laguna di Santa Caterina (Sardegna sud-occidentale). Coll Phytosoc 19:329-340

De Martis G, Mulas B, Malavasi V, Marignani M (2016) Can artificial ecosystems enhance local biodiversity? The case of a constructed wetland in a Mediterranean urban context. Environmental Management 57:1088-1097. https://doi.org/10.1007/s00267-0160668-4

De Miranda M, Gaviano M, Serra E (2005) Changes in the cell size of the diatom Cylindrotheca closterium in a hyperhaline pond. Chemistry and Ecology 21:77-81. https://doi.org/10.1080/ 02757540512331323962

Deil U (2005) A review on habitats, plant traits and vegetation of ephemeral wetlands-a global perspective. Phytocoenologia 35:533-705. https://doi.org/10.1127/0340-269X/2005/0035-0533

Désamoré A, Laenen B, Stech M, Papp B, Hedenäs L, Mateo RG, Vanderpoorten A (2012) How do temperate bryophytes face the challenge of a changing environment? Lessons from the past and predictions for the future. Global Change Biology 18:2915-2924. https://doi.org/10.1111/j.1365-2486.2012.02752.x

Desfayes M (2008) Flore vasculaire herbacée des eaux douces et des milieux humides de la Sardaigne. Fl Med 18:247-331

Dittrich S, Jacob M, Bade C, Leuschner C, Hauck M (2014) The significance of deadwood for total bryophyte, lichen and vascular plant diversity in an old-growth spruce forest. Plant Ecology 215:1123 1137

EC-European Commission (2017) LIFE and Coastal Habitats, Luxembourg. Available from: http://ec.europa.eu/environment/life/ publications/lifepublications/lifefocus/documents/coastal habitats. pdf

EEA-European Environment Agency (2015) State of nature in the EU. EEA Technical report No 2/2015, Copenhagen. Available from: https://www.eea.europa.eu/publications/state-of-nature-in-the-eu

Engle VD (2011) Estimating the provision of ecosystem services by Gulf of Mexico coastal wetlands. Wetlands 31:179-193. https://doi.org/ 10.1007/s13157-010-0132-9

Ferchichi-Ben Jamaa H, Muller SD, Ghrabi-Gammar Z, Rhazi L, SouliéMärsche I, Gammar AM et al (2014) Influence du pâturage sur la structure, la composition et la dynamique de la végétation de mares temporaires méditerranéennes (Tunisie septentrionale). Rev Écol 69:196-213

Ferrarini A, Celada C, Gustin M (2020) Preserving the Mediterranean bird flyways: assessment and prioritization of 38 main wetlands under human and climate threats in Sardinia and Sicily (Italy). Sci 
Total Environ 751:141556. https://doi.org/10.1016/j.scitotenv.2020. 141556

Filippino G (2018) Distribution, ecology and conservation of bryoflora in the Mediterranean temporary ponds $[\mathrm{PhD}$ thesis-University of Cagliari]

Fiocca F, Lugliè A, Sechi N (1996) The phytoplankton of S'Ena Arrubia lagoon (Centre-western Sardinia) between 1990 and 1995. Plant Biosyst 130:1016-1031.https://doi.org/10.1080/ 11263509609438385

Fois M, Fenu G, Cañadas EM, Bacchetta G (2017) Disentangling the influence of environmental and anthropogenic factors on the distribution of endemic vascular plants in Sardinia. PloS one. 12(8): e0182539. https://doi.org/10.1371/journal.pone.0182539

Fois M, Bacchetta G, Cogoni D, Fenu G (2018) Current and future effectiveness of the Natura 2000 network for protecting plant species in Sardinia: a nice and complex strategy in its raw state? Journal of Environmental Planning and Management 61:332-347. https://doi. org/10.1080/09640568.2017.1306496

Fumanti B, Cavacini P (2002) La flora algale degli Stagni del Molentargius (Cagliari). Webbia 57:217-244. https://doi.org/10. 1080/00837792.2002.10670736

Fuselier LC, Donarski D, Novacek J, Rastedt D, Peyton C (2012) Composition and biomass productivity of bryophyte assemblages in natural and restored marshes in the prairie pothole region of northern Minnesota. Wetlands 32:1067-1078. https://doi.org/10. 1007/s13157-012-0337-1

Gignac LD (2001) Bryophytes as indicators of climate change. The Bryologist 104:410-420. https://www.jstor.org/stable/3244774

Ginesu S (2012) A new lake in Italy (South-Western Sardinia): a maar? Geogr Fis Dinam Quat 35:177-184. https://doi.org/10.4461/GFDQ. 2012.35.16

Godet L, Devictor V (2018) What conservation does. Trends in Ecology \& Evolution 33:720-730. https://doi.org/10.1016/j.tree.2018.07. 004

Hallingbäck T, Hodgetts N (compilers) (2000) Mosses, Liverworts, and Hornworts. Status Survey and Conservation Action Plan for Bryophytes. IUCN/SSC Bryophyte Specialist Group. IUCN, Gland, Switzerland and Cambridge, UK. 3-5pp

Hobohm C, Bruchmann I (2011) Are there endemic vascular plants in wet habitats of Europe. Transylvanian Review of Systematical and Ecological Research 12:1-14

Hodgetts NG, Cálix M, Englefield E, Fettes N, Garcia Criando M, Patin L et al (2019) A miniature world in decline - European red list of mosses, liverworts and hornworts. IUCN

Kao JT, Titus JE, Zhu WX (2003) Differential nitrogen and phosphorus retention by five wetland plant species. Wetlands 23:979-987

Koenig I, Feldmeyer-Christe E, Mitchell EA (2015) Comparative ecology of vascular plant, bryophyte and testate amoeba communities in four Sphagnum peatlands along an altitudinal gradient in Switzerland. Ecological Indicators 54:48-59

Lai S, Leone F, Zoppi C (2017) Land cover changes and environmental protection: a study based on transition matrices concerning Sardinia (Italy). Land Use Policy 67:126-150. https://doi.org/10.1016/j. landusepol.2017.05.030

Lai GG, Padedda BM, Pulina S, Virdis T, Sechi N, Lugliè A (2010) Diatoms and quality of watercourses in north-Central Sardinia. Vie et milieu 60:209-216

Leberger R, Geijzendorffer IR, Elie G, Anis G, Galewski T, Pereira HM, Guerra CA (2020) Mediterranean wetland conservation in the context of climate and land cover change. Regional Environmental Change 20(2). https://doi.org/10.1007/s10113-020-01655-0

Legrand C, Rengefors K, Fistarol GO, Graneli E (2003) Allelopathy in phytoplankton-biochemical, ecological and evolutionary aspects. Phycologia 42:406-419. https://doi.org/10.2216/i0031-8884-42-4406.1
Lugliè A, Aktan, Y, Casiddu P, Sechi N (2001) The trophic status of Bidighinzu Reservoir (Sardinia) before and after the diversion of waste waters. J Limnol 60:135-142. https://doi.org/10.4081/ jlimnol.2001.1.135

Malavasi V (2012) Contributo alla conoscenza delle microalghe d'acqua dolce dei Tacchi d'Ogliastra (Sardegna centro-orientale). Inform Bot Ital 44:321-328

Manoylov KM (2014) Taxonomic identification of algae (morphological and molecular): species concepts, methodologies, and their implications for ecological bioassessment. Journal of Phycology 50:409424. https://doi.org/10.1111/jpy.12183

Manzano S, Carrión JS, García-Murillo P, López-Merino L (2019) When dynamism is the baseline: long-term ecology of a Mediterranean seasonal wetland in the Doñana National Park (southwestern Europe). Biodiversity and Conservation 28:501-522. https://doi. org/10.1007/s10531-018-1674-Z

Marazzi L, Gaiser EE, Eppinga MB, Sah JP, Zhai L, Castañeda-Moya E, Angelini C (2019) Why do we need to document and conserve foundation species in freshwater wetlands? Water 11:265. https:// doi.org/10.3390/w11020265

Mariani MA, Lai GG, Padedda BM, Pulina S, Sechi N, Virdis T, Lugliè A (2015) Long-term ecological studies on phytoplankton in Mediterranean reservoirs: a case study from Sardinia (Italy). Inland Waters 5:339-354. https://doi.org/10.5268/IW-5.4.868

Marignani M, Lussu M, Murru V, Bacaro G, Cogoni A (2020) Effect of invasive alien species on the co-occurrence patterns of bryophytes and vascular plant species - the case of a mediterranean disturbed sandy coast. Diversity 12:160. https://doi.org/10.3390/d12040160

Marty JT (2015) Loss of biodiversity and hydrologic function in seasonal wetlands persists over 10 years of livestock grazing removal. Restoration Ecology 23:548-554. https://doi.org/10.1111/rec.12226

Massoli-Novelli R, Mocci-Demartis A (1989) Le zone umide della Sardegna. Editoriale Olimpia

Mayoral O, Mascia F, Podda L, Laguna E, Fraga P, Rita J, Frigau L, Bacchetta G (2018) Alien plant diversity in Mediterranean wetlands: a comparative study within Valencian, Balearic and Sardinian floras. Not bot Horti Agrobot Cluj Napoca 46:317-326. https://doi.org/10. $15835 /$ nbha46210470

Melis MG, Zedda M, Manca L (2012) Marine and inland water resources in Eneolithic communities. New data from Sardinia (Italy). J Life Sci 6:679-693

Murphy K, Efremov A, Davidson TA, Molina-Navarro E, Fidanza K, Betiol TCC et al (2019) World distribution, diversity and endemism of aquatic macrophytes. Aquatic Botany 158:103127. https://doi. org/10.1016/j.aquabot.2019.06.006

Oliver MJ, Velten J, Wood AJ (2000) Bryophytes as experimental models for the study of environmental stress tolerance: Tortula ruralis and desiccation-tolerance in mosses. Plant Ecology 151: 73-84. https://doi.org/10.1023/A:1026598724487

Padedda BM, Pulina S, Magni P, Sechi N, Lugliè A (2012) Phytoplankton dynamics in relation to environmental changes in a phytoplankton-dominated Mediterranean lagoon (Cabras lagoon, Italy). Advances in Oceanography and Limnology 3:147-169. https://doi.org/10.1080/19475721.2012.716792

Padedda BM, Sechi N, Lai GG, Mariani MA, Pulina S, Sarria M, Satta CT, Virdis T, Buscarinu P, Luglie A (2017) Consequences of eutrophication in the management of water resources in Mediterranean reservoirs: a case study of Lake Cedrino (Sardinia, Italy). Glob Ecol Conserv 12:21-35. https://doi.org/10.1016/j.gecco.2017.08.004

Pascucci V, De Falco G, Del Vais C, Sanna I, Melis RT, Andreucci S (2018) Climate changes and human impact on the Mistras coastal barrier system (W Sardinia, Italy). Marine Geology 395:271-284

Pyke CR, Marty J (2005) Cattle grazing mediates climate change impacts on ephemeral wetlands. Conservation Biology 19:1619-1625. https://doi.org/10.1111/j.1523-1739.2005.00233.x 
Popiela A (2005) Isoëto-Nanojuncetea species and plant communities in their eastern distribution range (Poland). Phytocoenologia 35:283303. https://doi.org/10.1127/0340-269X/2005/0035-0283

Rahman MA, Reichman SM, De Filippis L, Sany SBT, Hasegawa H (2016) Phytoremediation of toxic metals in soils and wetlands: concepts and applications. In Environmental remediation technologies for metal-contaminated soils Springer, pp 161-195

Ramsar Convention Secretariat (2010) Designating Ramsar sites: strategic framework and guidelines for the future development of the list of wetlands of international importance, Ramsar handbooks for the wise use of wetlands, $4^{\text {th }}$ edition, vol 17 . Ramsar Convention Secretariat

Ramsar Convention Secretariat (2013) The Ramsar convention manual, $6^{\text {th }}$ Edition. Ramsar Convention Secretariat, Gland. http://www. ramsar.org/sites/default/files/documents/library/manual6-2013-e. pdf

Ramsar Convention Secretariat (2015) Regional overview of the implementation of the Convention and its Strategic Plan in Europe, Report to the 12th Meeting of the Conference of the Parties to the Convention on Wetlands, Punta del Este, Uruguay, 1-9 June 2015-Ramsar COP12 Doc.11 (2015) http://www.ramsar.org/ sites/default/files/documents/library/cop12_doc11_summary_ europe e.pdf

Ravera S, Puglisi A, Vizzini A, Totti C, Barberis G, Bianchi E et al (2020) Notulae to the Italian flora of algae, bryophytes, fungi and lichens: 10. Italian botanist 10:83-99. https://doi.org/10.3897/ italianbotanist.99.59352

Ricaurte LF, Jokela J, Siqueira A, Núñez-Avellaneda M, Marin C, Velázquez-Valencia A, Wantzen KM (2012) Wetland habitat diversity in the Amazonian Piedmont of Colombia. Wetlands 32:11891202. https://doi.org/10.1007/s13157-012-0348-y

Rivieccio G, Bagella S, Bazan G, Bonini F, Caria MC, Dagnino D, Mariotti M, Turcato C, Gianguzzi L (2020) New national and regional annex I habitat records: from\# 16 to\# 20. Plant Sociol 57: 133-144. https://doi.org/10.3897/pls2020572/05

Ruiz E (2008) Management of Natura 2000 habitats. 3170 *Mediterranean temporary ponds. European Commission, Brussels

Saaltink RM, Dekker SC, Griffioen J, Wassen MJ (2018) Vegetation growth and sediment dynamics in a created freshwater wetland. Ecological Engineering 111:11-21. https://doi.org/10.1016/j. ecoleng.2017.11.020

Sangiorgio F, Fonnesu A, Pinna M, Sabetta L, Basset A (2006) Influence of drought and abiotic factors on Phragmites australis leaf decomposition in the river Pula, Sardinia, Italy. Journal of Freshwater Ecology 21:411-420. https://doi.org/10.1080/02705060.2006. 9665018

Sannio A, Lugliè A, Sechi N (1996) The phytoplankton of the internal gulf of Olbia (north-East Sardinia) between July 1992 and July 1993. Plant Biosyst. 130:1037-1050. https://doi.org/10.1080/ 11263509609438387

Santamaría L (2002) Why are most aquatic plants widely distributed? Dispersal, clonal growth and small-scale heterogeneity in a stressful environment. Acta Oecologica 23:137-154. https://doi.org/10.1016/ S1146-609X(02)01146-3

Satta CT, Padedda BM, Sechi N, Pulina S, Loria A, Lugliè A (2017) Multiannual Chattonella subsalsa Biecheler (Raphidophyceae) blooms in a Mediterranean lagoon (Santa Giusta lagoon, Sardinia island, Italy). Harmful Algae 67:61-73. https://doi.org/10.1016/j. hal.2017.06.002

Schintu M, Cogoni A, Durante L, Cantaluppi C, Contu A (2005) Moss (Bryum radiculosum) as a bioindicator of trace metal deposition around an industrialised area in Sardinia (Italy). Chemosphere 60: $610-618$

Sciandrello S, Cambria S, Giusso del Galdo G, Guarino R, Minissale P, Pasta S, Tavilla G, Cristaudo A (2021) Floristic and vegetation changes on a small Mediterranean Island over the last century. Plants 10:680. https://doi.org/10.3390/plants 10040680

Sechi N, Cossu AVL (1985) Fitoplancton, nutrienti algali e stato trofico del lago Bunnari (Sardegna settentrionale). Boll Soc Sarda Sci Nat 24:61-74 ISSN 0392-6710

Sechi N, Lugliè A (1996) Phytoplankton in Sardinian reservoirs. Plant Biosyst 130:977-994. https://doi.org/10.1080/11263509609438380

Ucchesu M, Sarigu M, Del Vais C, Sanna I, D'Hallewin G, Grillo O, Bacchetta G (2017) First finds of Prunus domestica L. in Italy from the Phoenician and Punic periods $\left(6^{\text {th }}-2^{\text {nd }}\right.$ centuries BC). Veg Hist Archaeobot 26:539-549. https://doi.org/10.1007/s00334-017-06222

Wang Y, Molinos JG, Shi L, Zhang M, Wu Z, Zhang H, Xu J (2019) Drivers and changes of the Poyang Lake wetland ecosystem. Wetlands 39:35-44. https://doi.org/10.1007/s13157-019-01180-9

Webb JA, Wallis EM, Stewardson MJ (2012) A systematic review of published evidence linking wetland plants to water regime components. Aquatic Botany 103:1-14. https://doi.org/10.1016/j.aquabot. 2012.06.003

Van den Broeck M, Waterkeyn A, Rhazi L, Grillas P, Brendonck L (2015) Assessing the ecological integrity of endorheic wetlands, with focus on Mediterranean temporary ponds. Ecological Indicators 54:1-11

Van Rees CB, Waylen KA, Schmidt-Kloiber A, Thackeray SJ, Kalinkat G, Martens K et al (2020) Safeguarding freshwater life beyond 2020: Recommendations for the new global biodiversity framework from the European experience. Conserv Lett e12771. https://doi.org/ 10.1111/conl.12771, 14

Vogiatzakis IN, Mannion AM, Sarris D (2016) Mediterranean island biodiversity and climate change: the last 10,000 years and the future. Biodiversity and Conservation 25:2597-2627. https://doi.org/10. 1007/s10531-016-1204-9

Zacharias I, Dimitriou E, Dekker A, Dorsman E (2007) Overview of temporary ponds in the Mediterranean region: threats, management and conservation issues. Journal of Environmental Biology 28:1-9

Publisher's Note Springer Nature remains neutral with regard to jurisdictional claims in published maps and institutional affiliations. 